\title{
Evaluation of metals in water and sediments of micro-basins in the city of Americana, São Paulo state, Brazil
}

\author{
G. A. de Medeiros ${ }^{1}$, A. C. C. L. Tresmondi ${ }^{2}$, B. P. V. de Queiroz ${ }^{2}$, \\ C. A. Melo ${ }^{1}$, A. H. Rosa ${ }^{1}$, C. V. Negro ${ }^{2}$, L. F. Fraceto ${ }^{1}$ \\ \& A. I. Ribeiro ${ }^{1}$ \\ ${ }^{1}$ Universidade Estadual Paulista, UNESP,Campus de Sorocaba, Brazil \\ ${ }^{2}$ Centro Universitário Salesiano de São Paulo, UNISAL, \\ Campus Dom Bosco, Brazil
}

\begin{abstract}
Water pollution found in major rivers in Brazil has its origin from urban sewage discharges and industrial effluent, carried out by small streams and rivers crossing cities. Therefore, studies related to hydrographic micro-basins offer the opportunity to establish environmental management strategies for restoring water resources, based on diagnosis of the water quality. Despite this understanding, few studies in urban and rural areas have been performed in a systematic manner in Brazilian micro-basins. The main goal of this research was to diagnose the water resources in micro-basins in the region of the district of Americana, São Paulo state, Brazil, through the quantification of metals in water and sediment. The methodology was based on the investigation of metals (Ba, $\mathrm{Cd}, \mathrm{Cr}, \mathrm{Cu}, \mathrm{Fe}$, $\mathrm{Mn}, \mathrm{Ni}, \mathrm{Pb}, \mathrm{Zn}$ ), in four micro-basins, determined by inductively coupled plasma optical emission spectrometry (ICP-OES). The most significant result showed high concentration levels of chromium $\left(969 \mu \mathrm{g} \mathrm{\textrm {L } ^ { - 1 }}\right)$, downstream of the discharge of sewage from the city of Nova Odessa. This concentration in the river was above the allowed limit of Brazilian regulation agency $\left(50 \mu \mathrm{g} \mathrm{L}^{-1}\right.$ for $\mathrm{Cr})$. Also high levels of $\mathrm{Cr}$ were found in the sediment $\left(98.9 \mathrm{\mu g} \mathrm{g}^{-1}\right)$ collected at the same monitored site. These results are important indicators of environmental performance and anthropogenic activities to help the government establish environmental management strategies aimed at the reduction of water pollution. Keywords: water resources, water quality, chromium.
\end{abstract}




\section{Introduction}

The expressive growth of cities and industrial parks in Brazil took place in a disorderly way and without planning, having as one of its principal consequences the environmental degradation. According to Brazilian demographic census, the population in 1950 was around 52 million people, and from these people 36.1\% (18 million people) lived in urban areas. In 1970, with the urban population increase, about $56 \%$ of Brazilians lived in cities. In 2000 the urban population reached more than 137 million people, which corresponded to an urbanization rate of $81.2 \%$ (Girardi [1]). In the latest official estimates (2010) the Brazilian population reached around 190 million people, from which $84 \%$ was distributed in cities (IBGE [2]).

This irregular distribution of population in Brazil led to a scenario of water shortage in some regions, although approximately $10 \%$ of the total amount of available fresh water in the world is in Brazil. That is the reality of Piracicaba river basin, in the state of São Paulo, one of the most developed regions of Brazil, densely populated and industrialized, which faces problems related to water scarcity in quantity and quality.

Despite its economic importance for Brazil and the serious problems of water pollution, in Piracicaba river basin there are few researches addressing the scope of micro-basin. The latest is a territorial unit ideal for planning and management of water resources, because it allows a better evaluation of the functioning of physical, chemical and biological factor acting on the water cycle.

Among these researches, the diagnostic work on water quality in micro-basins developed by Medeiros et al. [3], in the city of Americana, Daniel et al. [4] and Fostier et al. [5], in the Piracicaba river basin, and Moreira and Fazza [6], in the county of Limeira, near Americana city, stand out. These works showed a scenario of significant degradation of water quality, basically by discarding of domestic sewage and industrial effluent without any treatment.

In the city of Americana, the outstanding textile industrial park produces effluents with the presence of metals such as cadmium and chromium and organic dyes.

In Brazil the literature regarding to the concentration of these metals in water and sediments of the Piracicaba river basin is limited and related to watersheds with medium to large drainage area (Mortatti and Probst [7]; Jardim et al. [8]; Leite [9]; Bonotto and Lima [10]).

In this way, the main goal of this research was to make a diagnosis of water resources in micro-watersheds in the region of Americana, São Paulo state, through the evaluation of metals in order to investigate the water quality of this region to give a support for the government to establish environmental management strategies aiming the reduction of water pollution. 


\section{Material and methods}

\subsection{Location and characterization of the micro-basins}

This work was performed in micro-basins located in the area surrounding the city of Americana, São Paulo state, Brazil.

Americana is a municipality whose population reached 210,638 people in 2010, with $99.5 \%$ living in urban areas. The territory of the municipality is 134 $\mathrm{km}^{2}$ leading to a population density of 1,580 hab. $\mathrm{km}^{-2}$.

The Americana gross domestic product in 2010 reached U.S. \$ 3.29 billion, $0.1 \%, 40.2 \%$ and $59.7 \%$ corresponding to the agricultural, manufacturing and services respectively (IBGE [11]). About 95\% of the county is served by the sewage network and $85 \%$ of this volume is treated (SEPLAN [12]). In the industrial area the textiles and clothing producer sector prevails and it represents $63.2 \%$ of the 2,941 registered industries in American in the year of 2011 (SEPLAN [12]).

All monitored streams are branches of Quilombo river, the main one that flows through the urban area of Americana and drains into the Piracicaba river. The micro-basins selected in this study corresponded to Recanto stream, Santa Angelica stream and Pylles stream (Figure 1).

The micro-watershed of the Recanto stream (Figure 2) covers the provinces of Americana and Nova Odessa. From this stream were chosen two sampling sites of water quality. The former an estuary (site 1), far about $250 \mathrm{~m}$ downstream of the discharge of sewage from the city of Nova Odessa, and the latter about $10 \mathrm{~m}$ upstream of this discharge effluent (site 2).

In micro-basins of Santa Angelica (site 3) and Pylles (site 4) streams sampling of water quality was collected from its mouth. The geographical coordinates of sampling locations of water quality, height, and the micro-basin area are shown in Table 1.

Table 1: $\quad$ Details of the sampling sites of water quality.

\begin{tabular}{|c|c|c|c|c|c|}
\hline Site & Stream & Latitude & Longitude & $\begin{array}{c}\text { Height } \\
(\mathrm{m})\end{array}$ & $\begin{array}{c}\text { Area } \\
\left(\mathrm{km}^{2}\right)\end{array}$ \\
\hline 1 & Recanto & $2^{\circ} 45^{\prime} 42^{\prime \prime} S$ & $47^{\circ} 19^{\prime} 01^{\prime \prime} \mathrm{W}$ & 538 & 23.9 \\
\hline 2 & Recanto & $22^{\circ} 45^{\prime} 47^{\prime \prime} \mathrm{S}$ & $47^{\circ} 19^{\prime} 10^{\prime \prime} \mathrm{W}$ & 540 & 23.6 \\
\hline 3 & Santa Angélica & $22^{\circ} 44^{\prime} 46^{\prime \prime} \mathrm{S}$ & $47^{\circ} 19^{\prime} 18^{\prime \prime} \mathrm{W}$ & 537 & 14.6 \\
\hline 4 & Pylles & $22^{\circ} 43^{\prime} 59^{\prime} \mathrm{S}$ & $4^{\circ} 19^{\prime} 55^{\prime \prime} \mathrm{W}$ & 536 & 3.3 \\
\hline
\end{tabular}

Recanto stream micro-basin relatively presents the smallest urban settlement, with $21 \%$ of its urban area $\left(4.9 \mathrm{~km}^{2}\right)$, and $79 \%$ rural $\left(18.7 \mathrm{~km}^{2}\right)$ (Medeiros et al. [3]). The Pylles stream is inserted in a region more urbanized, corresponding to $77 \%$ of the basin, or $2.5 \mathrm{~km}^{2}$, leaving $23 \%$ for maintaining sparse vegetation. Finally the Santa Angelica stream micro-basin has $63 \%$ of its urbanized area $(9.2$ $\mathrm{km}^{2}$ ) and $37 \%$ vegetated with grasses and riparian vegetation $\left(5.4 \mathrm{~km}^{2}\right)$. 


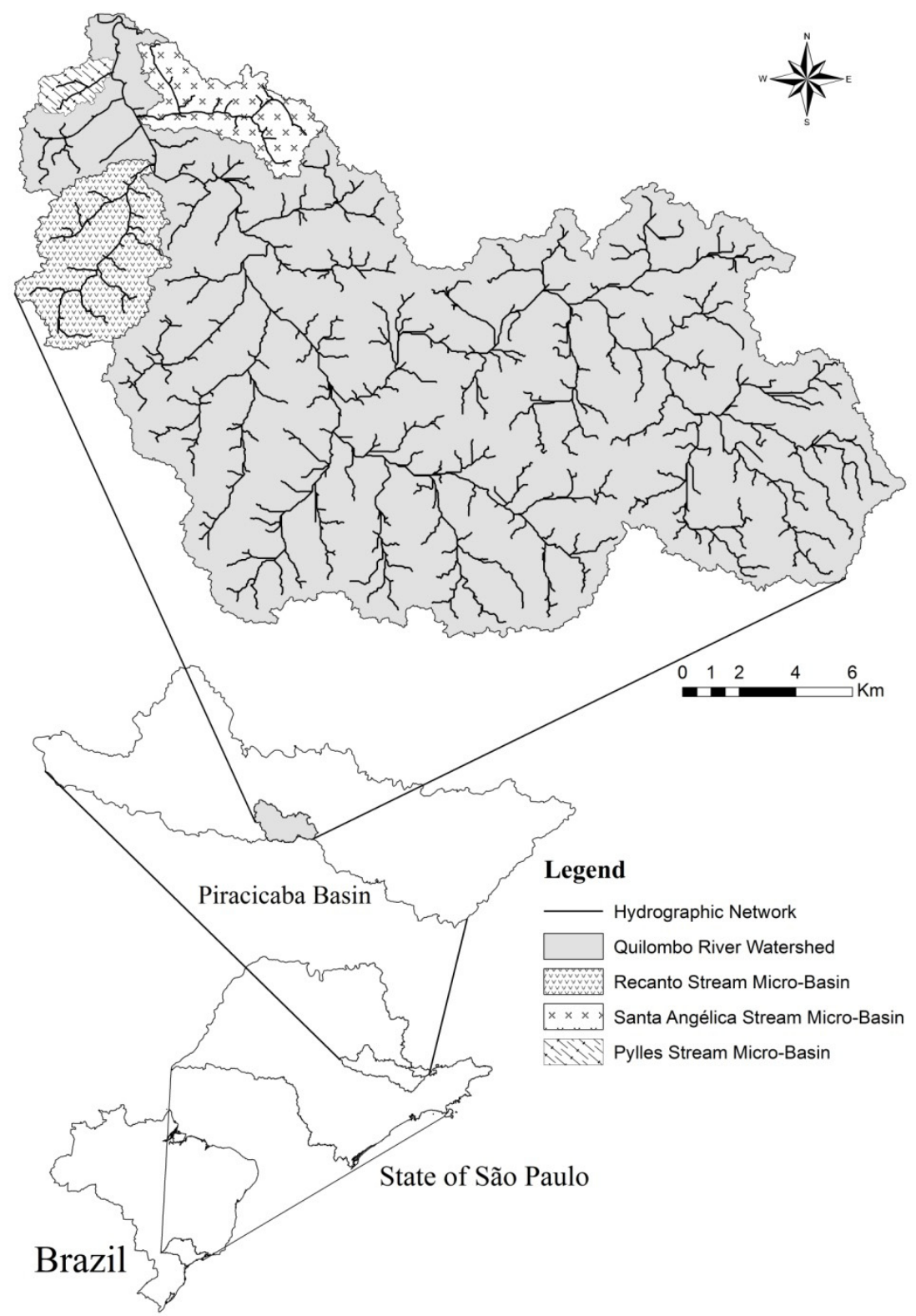

Figure 1: $\quad$ Micro-basins monitored in Quilombo river basin. 


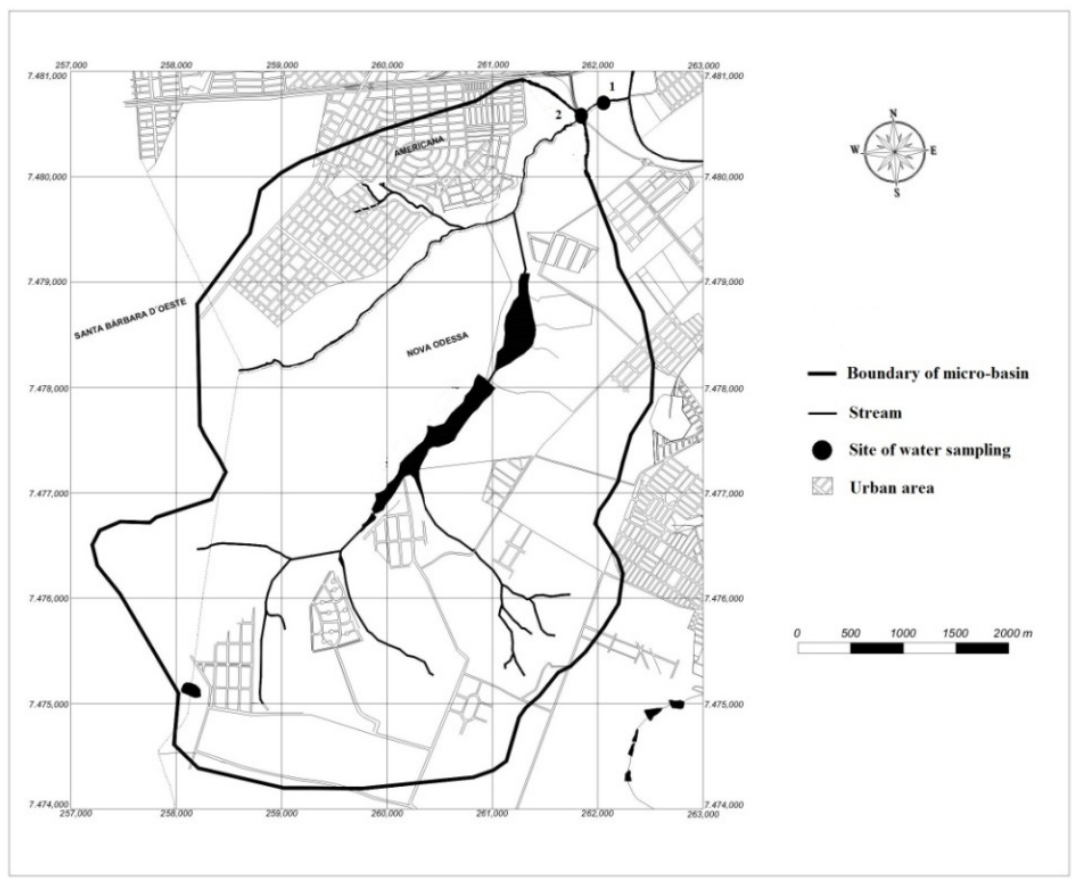

Figure 2: Monitoring sites of water quality in the Recanto stream (adapted from Medeiros et al. [3]).

Considering the climatic classification of Köppen, in the place where the micro-basins are located, this corresponds to tropical wet and dry or savanna climate (Aw) having a pronounced dry season, with the driest month having rain less than $60 \mathrm{~mm}$ and a mean monthly temperature above $18^{\circ} \mathrm{C}$ (Medeiros et al. [3]).

The total annual rainfall reaches an average of $1291.8 \mathrm{~mm}$. In January, the wettest, the average rainfall is around $239 \mathrm{~mm}$, while in July, the driest month, the rainfall corresponds to an average of $27.3 \mathrm{~mm}$ (CEPAGRI [13]). The average annual minimum and maximum temperature reached 15.3 and $28.2^{\circ} \mathrm{C}$ respectively while the mean annual temperature is $21.8^{\circ} \mathrm{C}$, being July the coldest month, which has an average of $18^{\circ} \mathrm{C}$, and the hottest corresponds to February, when it reaches an average of $24.6^{\circ} \mathrm{C}$ (CEPAGRI [13]).

\subsection{Study of flow streams}

The flow measurement was performed at the same time of water sampling in the micro-basins using a mechanical flow meter (Global Water Flow Probe, model FP111) having a measuring range from 0.3 to $19.9 \mathrm{ft} \mathrm{s}^{-1}$ and an accuracy of 0.1 ft.s . $^{-1}$. 


\subsection{Investigation of metals concentration in water and sediment}

Samplings of water were collected from August 2011 until October 2012, covering the dry season (from April-September) and the rainy season (from October-March). The sediment sampling was carried out in November 2011.

Water samples were collected about $10 \mathrm{~cm}$ below the surface in streams and stored in a PET bottle of $1 \mathrm{~L}$, and acidified to give a $\mathrm{pH}$ lower than 2.0. These samples, kept on ice, were transported to the laboratory and analyzed according to the procedure recommended by AWWA [14]. For all sample sites, the metal concentrations were analyzed in triplicate.

The results were compared with the water quality parameters established by the Environmental Company of the São Paulo state - CETESB for Class 2 rivers, object of the present work. These patterns are presented in Table 2.

Table 2: $\quad$ Water quality parameters for Class 2 river, Brazil (CETESB [15]).

\begin{tabular}{|l|c|l|c|}
\hline \multicolumn{1}{|c|}{ Metal } & Limit $\left(\mu \mathrm{L} \mathrm{L}^{-1}\right)$ & \multicolumn{1}{|c|}{ Metal } & Limit $\left(\mu \mathrm{g} \mathrm{L}^{-1}\right)$ \\
\hline Total Barium $(\mathrm{Ba})$ & 700.0 & Total Lead $(\mathrm{Pb})$ & 10.0 \\
\hline $\begin{array}{l}\text { Total Cadmium } \\
(\mathrm{Cd})\end{array}$ & 1.0 & Total Zinc $(\mathrm{Zn})$ & ------- \\
\hline $\begin{array}{l}\text { Total Chromium } \\
(\mathrm{Cr})\end{array}$ & 50.0 & Total Iron $(\mathrm{Fe})$ & 100.0 \\
\hline Total Copper $(\mathrm{Cu})$ & ------- & $\begin{array}{l}\text { Total Manganese } \\
(\mathrm{Mn})\end{array}$ & \\
\hline Total Nickel $(\mathrm{Ni})$ & 25.0 & & \\
\hline
\end{tabular}

In the sediment samples, also analyzed in triplicate, preparation followed the methodology recommended by Ure [16] and Basilio et al. [17]. We analyzed the results of chemical quality of the sediments based on values established by the Canadian Council of Ministers of the Environment - CCME (CCME, [18]) and adopted by CETESB in the São Paulo state. Table 3 presents the standard used for the analysis of the chemical quality of sediment where TEL (Threshold Effect Level) is the concentration below which adverse effects are seldom expected for the organisms and PEL (Probable Effect Level) is the concentration above which is often expected adverse effect for the organisms.

Table 3: $\quad$ Sediment quality parameters adopted in the São Paulo state, Brazil (CETESB [15]).

\begin{tabular}{|c|c|c|c|c|c|}
\hline Metal & TEL & PEL & Metal & TEL & PEL \\
\hline & $\left(\mu \mathrm{g} \mathrm{g}^{-1}\right)$ & $\left(\mu \mathrm{g} \mathrm{g}^{-1}\right)$ & & $\left(\mu \mathrm{g} \mathrm{g}^{-1}\right)$ & $\left(\mu \mathrm{g} \mathrm{g}^{-1}\right)$ \\
\hline $\mathrm{Ba}$ & ------- & ------ & $\mathrm{Pb}$ & 35.0 & 91.3 \\
\hline $\mathrm{Cd}$ & 0.6 & 3.5 & $\mathrm{Zn}$ & 123.0 & 315.0 \\
\hline $\mathrm{Cr}$ & 37.3 & 90.0 & $\mathrm{Fe}$ & ------- & ------- \\
\hline $\mathrm{Cu}$ & 35.7 & 197.0 & $\mathrm{Mn}$ & ------- & ------ \\
\hline $\mathrm{Ni}$ & 18.0 & 35.9 & & & \\
\hline
\end{tabular}


The analyses of total $\mathrm{Ba}, \mathrm{Cd}, \mathrm{Cr}, \mathrm{Cu}, \mathrm{Ni}, \mathrm{Pb}, \mathrm{Zn}, \mathrm{Fe}$ and $\mathrm{Mn}$ of the sediment and water amount were performed in the Laboratory of Environmental Chemistry and Analysis Traces of UNESP, Sorocaba, using Inductively Coupled Plasma Optical Emission Spectrometry (ICP -OES, Agilent-720) with nebulizer type "seaspray".

The experimental conditions used were: radiofrequency power of $1.10 \mathrm{~kW}$, argon flow of plasma from $15.0 \mathrm{~L} \mathrm{~min}^{-1}$ and the nebulizer pressure of $200 \mathrm{kPa}$. Standard solutions of multielement calibration were used and prepared from a stock solution multielement $\left(100.0 \mathrm{mg} \mathrm{L}^{-1}\right)$. The detection limits were calculated by evaluating the deviation of reading from ten analytical white. The detection limit was $0.8 \mu \mathrm{g} \mathrm{L}{ }^{-1}$ to $\mathrm{Ba}$; $1.1 \mu \mathrm{g} \mathrm{L}^{-1}$ to $\mathrm{Cd}$; $3.4 \mu \mathrm{g} \mathrm{L}^{-1}$ to $\mathrm{Cr}$; $3.2 \mu \mathrm{g} \mathrm{L}^{-1}$ to $\mathrm{Cu}$; $74.1 \mu \mathrm{g} \mathrm{L}{ }^{-1}$ to Fe; $2.0 \mu \mathrm{g} \mathrm{L}^{-1}$ to $\mathrm{Mn} ; 1.4 \mu \mathrm{g} \mathrm{L}{ }^{-1}$ to $\mathrm{Ni} ; 12.4 \mu \mathrm{g} \mathrm{L}^{-1}$ to $\mathrm{Pb}$ and $2.5 \mu \mathrm{g}$ $\mathrm{L}^{-1}$ to $\mathrm{Zn}$.

\section{Results}

Figure 3 shows the variation of flow in the monitored streams during the period from 30 August 2011 until 23 October 2012. In Recanto, Santa Angelica and Pylles streams the range of observed flow varied from 0.10 to $0.48 \mathrm{~m}^{3} \mathrm{~s}^{-1} ; 0.03$ to $0.81 \mathrm{~m}^{3} \mathrm{~s}^{-1}$ and 0.03 to $0.17 \mathrm{~m}^{3} \mathrm{~s}^{-1}$ respectively. These values are proportional to the observed temporal distribution of rainfall in the region.

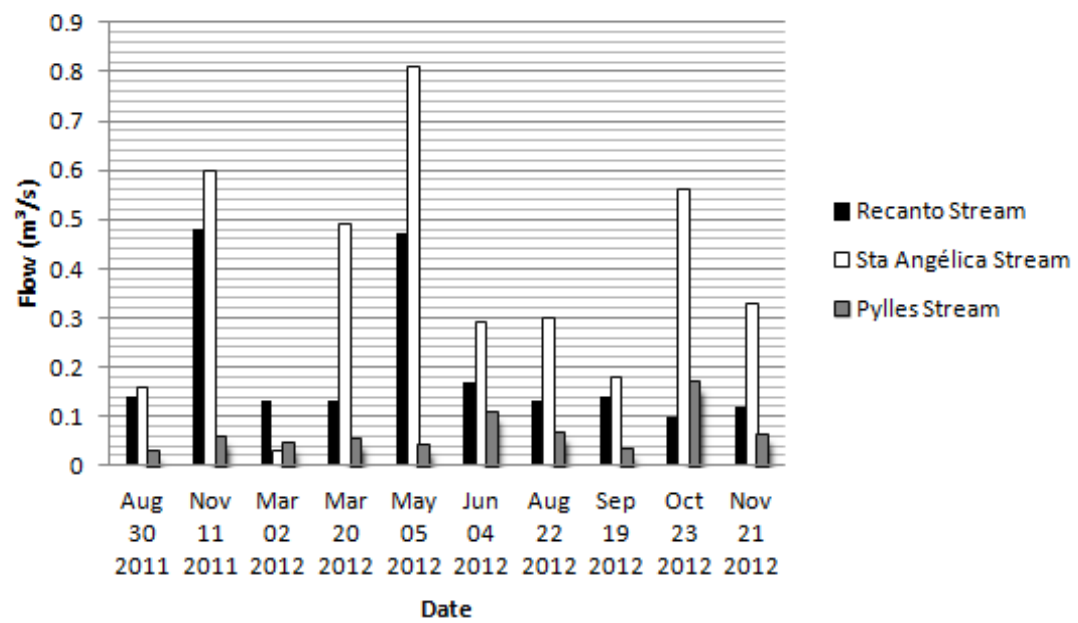

Figure 3: Flow from streams of the city of Americana, São Paulo state, Brazil.

Results of metal analysis in water are shown in Table 4, where Mean is the average; Max is the maximum value; Min corresponds to minimum value; STD is the standard deviation; and $\mathrm{n}$ the number of observations. It is observed that the Recanto stream presented the highest concentrations of metals in relation to 
other creeks, indicating a higher degradation of water quality. Medeiros et al. [3] evaluated the physical and chemical quality of the water of this stream, upstream of domestic sewage from Nova Odessa, and could identify the water pollution due to discharge of effluents from domestic sources of the city of Americana.

It was possible to verify by the analysis of the results from Table 4, a strong influence of domestic sewage of the city of Nova Odessa on the water quality of this stream, mainly regarding metals $\mathrm{Zn}, \mathrm{Ni}, \mathrm{Cu}, \mathrm{Cr}$ and $\mathrm{Pb}$ that have increased $1110 \%, 770 \%, 487 \%, 263 \%$ and $130 \%$ respectively, from site 2 to site 1 .

Table 4: Metals in water from micro-basins, Americana city, São Paulo state, Brazil.

\begin{tabular}{|c|c|c|c|c|c|c|c|c|c|c|}
\hline Site & Stat & $\mathrm{Ba}$ & $\mathrm{Cd}$ & $\mathrm{Cr}$ & $\mathrm{Cu}$ & $\mathrm{Ni}$ & $\mathrm{Pb}$ & $\mathrm{Zn}$ & $\mathrm{Fe}$ & $\mathrm{Mn}$ \\
\hline & & & 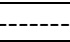 & ---- & $\mu \mathrm{g} \mathrm{L}^{-1}$ & & ------ & & $\mathrm{mg}$ & -1 \\
\hline \multirow{5}{*}{1} & Mean & 281.7 & $<1.1$ & 408.1 & 244.4 & 210.3 & 66.3 & 4489.1 & 37.15 & 1.50 \\
\hline & Max & 490.4 & 1.5 & 981.2 & 397.9 & 496.1 & 99.5 & 6900.0 & 59.70 & 2.60 \\
\hline & Min & 117.3 & $<1.1$ & 85.5 & 20.1 & 8.2 & 20.0 & 155.4 & 16.80 & 0.70 \\
\hline & SD & 109.4 & ----- & 371.4 & 151.3 & 233.8 & 30.6 & 2788.0 & 18.58 & 0.73 \\
\hline & $\mathrm{n}$ & 8 & 11 & 11 & 8 & 8 & 8 & 8 & 8 & 8 \\
\hline \multirow{5}{*}{2} & Mean & 262.7 & $<1.1$ & 77.6 & 25.1 & 13.6 & 25.4 & 202.0 & 39.08 & 1.37 \\
\hline & Max & 384.4 & 1.1 & 170.1 & 53.6 & 29.5 & 48.5 & 383.2 & 67.60 & 2.40 \\
\hline & Min & 159.4 & $<1.1$ & 34.9 & 9.1 & 2.6 & 13.3 & 73.2 & 12.80 & 0.38 \\
\hline & SD & 92.6 & ----- & 54.2 & 15.8 & 12.7 & 11.9 & 105.5 & 23.31 & 0.70 \\
\hline & $\mathrm{n}$ & 8 & 11 & 11 & 8 & 8 & 8 & 8 & 8 & 8 \\
\hline \multirow{5}{*}{3} & Mean & 200.7 & $<1.1$ & 21.3 & 16.5 & 7.1 & 14.3 & 113.8 & 14.93 & 0.40 \\
\hline & Max & 370.5 & $<1.1$ & 48.5 & 31.8 & 21.1 & 39.4 & 170.7 & 21.20 & 0.44 \\
\hline & Min & 63.2 & $<1.1$ & 1.0 & 6.6 & 1.4 & 20.0 & 93.1 & 12.10 & 0.34 \\
\hline & SD & 141.3 & ---- & 18.1 & 9.2 & 8.2 & 14.1 & 26.9 & 2.98 & 0.04 \\
\hline & $\mathrm{n}$ & 8 & 10 & 10 & 8 & 8 & 8 & 8 & 8 & 8 \\
\hline \multirow{5}{*}{4} & Mean & 420.0 & $<1.1$ & 14.5 & 20.9 & 9.9 & 19.1 & 227.5 & 11.99 & 3.70 \\
\hline & Max & 948.4 & 3.1 & 35.6 & 45.6 & 32.1 & 44.1 & 580.3 & 16.70 & 5.50 \\
\hline & Min & 25.3 & $<1.1$ & 1.0 & 4.4 & 1.4 & 2.0 & 93.7 & 4.70 & 0.32 \\
\hline & SD & 401.8 & ----- & 14.8 & 17.1 & 14.5 & 17.1 & 169.9 & 5.08 & 2.38 \\
\hline & $\mathrm{n}$ & 8 & 11 & 11 & 8 & 8 & 8 & 8 & 8 & 8 \\
\hline
\end{tabular}

Such increases in the concentration of these metals indicate that industrial discharges occurred in the sewage disposal system of Nova Odessa, during the period of the present study. $\mathrm{Cr}$ is used in the textile industry to preserve, printing and dyeing (McGrath [19]); and $\mathrm{Zn}, \mathrm{Cu}, \mathrm{Pb}$ and $\mathrm{Ni}$ are present in sewage sludge from smelter industry (Baker and Senft [20], Davies [21] and Kiekens [22]).

The metals $\mathrm{Ba}, \mathrm{Cd}$ and $\mathrm{Zn}$ had concentrations below the limits established by Brazilian legislation (CETESB [15]) for Class 2 rivers. However the $\mathrm{Cr}, \mathrm{Ni}, \mathrm{Pb}$ and Mn exceeded the limits established by Brazilian legislation for these monitored streams, especially in Recanto stream.

Comparing the results of water analysis from Table 4 with those of Quilombo river in the City of American, which receives the outflow from all streams evaluated, there is a variation in the Fe concentration from 2.6 to $99.0 \mathrm{mg} \mathrm{L}^{-1}$ in 2011, which includes the range of values observed in this study. The minimum 
value of Fe concentration was $4.7 \mathrm{mg} \mathrm{L}^{-1}$ in Pylles stream and the maximum 67.6 at Recanto stream. Therefore, it is concluded that high levels of iron are associated with chemical properties of subtropical soils of the region.

The concentrations of $\mathrm{Cr}, \mathrm{Cu}, \mathrm{Ni}$ and $\mathrm{Pb}$, presented in Table 4 for the Recanto stream, in both sampling sites were much higher those observed in Quilombo river, in 2011. According to CETESB [15], Cr, $\mathrm{Cu}, \mathrm{Ni}, \mathrm{Pb}$ and $\mathrm{Zn}$ in Quilombo river ranged from $<7 \mu \mathrm{g} \mathrm{L}^{-1}$ to $<30 \mu \mathrm{g} \mathrm{L}^{-1}$; from $<10 \mu \mathrm{g} \mathrm{L}^{-1}$ to $19 \mu \mathrm{g} \mathrm{L}^{-1}$; from $<10 \mu \mathrm{g} \mathrm{L}^{-1}$ to $30 \mu \mathrm{g} \mathrm{L}^{-1}$; from $<5 \mu \mathrm{g} \mathrm{L}^{-1}$ to $10 \mu \mathrm{g} \mathrm{L}^{-1}$ and from $10 \mu \mathrm{g} \mathrm{L}^{-1}$ to $40 \mu \mathrm{g}$ $\mathrm{L}^{-1}$ respectively. This result demonstrates the pollution potential of urban streams on larger rivers and reservoirs that are usually used to supply the industrial park in the region, such as Quilombo river.

Moreira and Fazza [6] verified metals pollution in water and sediments of urban micro-basins in the county of Limeira, beside Americana city. In water samples, were observed average concentrations for $\mathrm{Fe}, \mathrm{Zn}, \mathrm{Cr}, \mathrm{Ni}, \mathrm{Cu}$ and $\mathrm{Pb}$ reaching 14,300 $\mu \mathrm{g} \mathrm{L}^{-1} ; 1,010 \mu \mathrm{g} \mathrm{L}^{-1} ; 1,085 \mu \mathrm{g} \mathrm{L}^{-1} ; 207 \mu \mathrm{g} \mathrm{L}^{-1} ; 194 \mu \mathrm{g} \mathrm{L}^{-1}$ and $876 \mu \mathrm{g} \mathrm{L}{ }^{-1}$ respectively, demonstrating a scenario of environmental pollution of water bodies in the region of Americana city.

Results of water quality observed in Table 4 are in agreement with those presented in Table 5, because the area with increased contamination of sediments corresponds to the Recanto stream, downstream of the discharge of sewage from Nova Odessa. It was not possible to collect the sediment from site 4, as the margins and bottom of the Pylles stream were lined with concrete.

Table 5: $\quad$ Metals in sediments from micro-basins, Americana city, São Paulo state, Brazil.

\begin{tabular}{|c|c|c|c|c|c|c|c|c|c|c|}
\hline Site & Stat & $\mathrm{Ba}$ & $\mathrm{Cd}$ & $\mathrm{Cr}$ & $\mathrm{Cu}$ & $\mathrm{Ni}$ & $\mathrm{Pb}$ & $\mathrm{Zn}$ & $\mathrm{Fe}$ & $\mathrm{Mn}$ \\
\hline & & & & 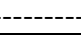 & ------ & $\mu \mathrm{g} \mathrm{g}^{-}$ & 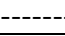 & -- & & \\
\hline \multirow{5}{*}{1} & Mean & 25.6 & $<0.1$ & 98.9 & 23.9 & 16.5 & 6.0 & 101.7 & 26065 & 93.9 \\
\hline & Max & 26.7 & $<0.1$ & 110.0 & 26.7 & 18.3 & 6.4 & 103.3 & 28418 & 100.0 \\
\hline & Min & 25.0 & $<0.1$ & 88.3 & 21.7 & 15.1 & 5.8 & 98.3 & 24350 & 81.7 \\
\hline & SD & 1.0 & ----- & 10.8 & 2.5 & 1.7 & 0.3 & 2.9 & 2108 & 10.6 \\
\hline & $\mathrm{N}$ & 3 & 3 & 3 & 3 & 3 & 3 & 3 & 3 & 3 \\
\hline \multirow{5}{*}{2} & Mean & 17.8 & $<0.1$ & 42.8 & 12.0 & 0.2 & 6.2 & 72.2 & 9324 & 53.3 \\
\hline & Max & 23.3 & $<0.1$ & 60.0 & 16.2 & 0.4 & 9.4 & 96.7 & 16778 & 68.3 \\
\hline & Min & 8.5 & $<0.1$ & 18.3 & 4.8 & 0.0 & 2.5 & 31.7 & 5465 & 23.3 \\
\hline & SD & 8.1 & ----- & 21.8 & 6.3 & 0.2 & 3.5 & 35.4 & 6457 & 26.0 \\
\hline & $\mathrm{N}$ & 3 & 3 & 3 & 3 & 3 & 3 & 3 & 3 & 3 \\
\hline \multirow{5}{*}{3} & Mean & 4.6 & $<0.1$ & 5.9 & 5.9 & 0.0 & 0.9 & 8.6 & 5867 & 36.7 \\
\hline & Max & 5.3 & $<0.1$ & 6.5 & 9.6 & 0.0 & 1.3 & 10.2 & 6757 & 40.0 \\
\hline & Min & 4.2 & $<0.1$ & 4.9 & 3.6 & 0.0 & 0.7 & 7.7 & 5420 & 35.0 \\
\hline & SD & 0.6 & ----- & 0.9 & 3.2 & 0.0 & 0.3 & 1.3 & 771 & 2.9 \\
\hline & $\mathrm{N}$ & 3 & 3 & 3 & 3 & 3 & 3 & 3 & 3 & 3 \\
\hline
\end{tabular}

Considering the limits established by Canadian Council of Ministers of the Environment and adopted by CETESB [14] for metals in freshwater sediments, only the $\mathrm{Cr}$ in Recanto stream (site 1) was the parameter above the upper limit 
(TEL), which ranged from 88.3 to $110 \mu \mathrm{g} \mathrm{g}^{-1}$, during the period of the experiment. The monitoring site upstream of the discharge of sewage from Nova Odessa (site 2), the Cr concentration in the sediment ranged from 18.3 to $60.0 \mu \mathrm{g}$ $\mathrm{g}^{-1}$, corresponding to a transition zone, in which occasionally adverse effects are expected for the organisms.

Also in the Recanto stream (site 1) other metal (total Nickel) showed a concentration around the transition zone.

There are few studies addressing the monitoring of sediment in streams in the region of the city of Americana, to have a basis for comparison with the results of this work. In this way, we highlight the work of Leite [9] conducted at Salto Grande reservoir in Americana.

Leite [9] measured higher concentrations of $\mathrm{Fe}, \mathrm{Mn}, \mathrm{Zn}, \mathrm{Cu}$ and $\mathrm{Cr}$ in sediments in the reservoir Salto Grande, in relation to those observed in this study, ranging from 43,220 to $246,270 \mu \mathrm{g} \mathrm{g}^{-1}$; from 303 to $1,070 \mu \mathrm{g} \mathrm{g}^{-1}$; from 55 to $350 \mu \mathrm{g} \mathrm{g}^{-1}$; from 15.4 to $328 \mu \mathrm{g} \mathrm{g}^{-1}$ and from 0 to $152 \mu \mathrm{g} \mathrm{g}^{-1}$ respectively.

In the city of Limeira, average concentration of the metals $\mathrm{Cr}, \mathrm{Zn}, \mathrm{Cu}, \mathrm{Ni}$ and $\mathrm{Pb}$, in sediment samples, reached $184 \mu \mathrm{g} \mathrm{g}^{-1} ; 486 \mu \mathrm{g} \mathrm{g}^{-1} ; 266 \mu \mathrm{g} \mathrm{g}^{-1} ; 13 \mu \mathrm{g} \mathrm{g}^{-1}$ and $107 \mu \mathrm{g} \mathrm{g}^{-1}$ respectively (Moreira and Fazza [6]).

\section{Conclusions}

The results of the current study demonstrate the potential pollution of urban streams in the city of Americana, and the scenario where degradation is due to the discharge of domestic sewage and industrial wastewater in a illegal manner, reflecting the high concentration values of $\mathrm{Cr}, \mathrm{Cu}, \mathrm{Ni}$ and $\mathrm{Pb}$.

These types of streams, in general, are not systematically monitored by environmental agencies in Brazil, despite their importance in the context for Brazilian water resources, especially in urban areas. Also, they are usually inserted into the territorial scope of a few municipalities, which could facilitate a sharing environmental management of the micro-watersheds involved, including the government, NGOs and organizations representing communities.

That is the case of the Recanto stream, in the city of Americana, where the source of its water pollution is the discharge of sewage from the city of Nova Odessa. This diagnosis points to the adoption of integrated management strategies between the governments of these cities to face the degradation of the water resources.

\section{Acknowledgements}

The authors thank the Pro Reitoria de Pesquisa, from Univ. Estadual Paulista (UNESP) for the financial support of the Programa Primeiros Projetos, Edital 05/2011.

Also the authors thank the Centro Universitário Salesiano (UNISAL) for providing scientific scholarship to C. V. Negro.

Finally the authors thank the following students' participation in data collection and chemical analyzes: Iris Sayuri Fukuda Tomaz (UNESP); Nami 
Ono (UNESP); Flaise Lauren Silva (UNESP); Renata Silva Lopes (UNISAL); Joziane Fialho Martins (UNISAL); Leandro Ferreira dos Santos (UNISAL).

\section{References}

[1] Girardi, E.P. Proposição teórico-metodológica de uma cartografia geográfica crítica e sua aplicação no desenvolvimento do atlas da questão agrária brasileira. UNESP: Presidente Prudente, Brazil, 2008 (in Portuguese).

[2] IBGE (Instituto Brasileiro de Geografia e Estatística). Available on http://www.ibge.gov.br/home/ Access on February 2, 2013.

[3] Medeiros, G.A., Archanjo, P., Simionato, R. and Reis, F.A.G.V. Diagnosis of the water quality of the Recanto Creek microbasin, at Americana, in the state of Sao Paulo, Brazil. Geociências, 28(2), p. 181-191, 2009. (in Portuguese).

[4] Daniel, M.H.B., Montebelo, A.A., Bernardes, M.C., Ometto, J.P.H.B. et al. Effects of urban sewage on dissolved oxygen, dissolved inorganic and organic carbon, and electrical conductivity of small streams along gradient of urbanization in the Piracicaba River Basin. Water, Air, and Soil Pollution, 136(1-4), p. 189-206, 2002.

[5] Fostier, A.-H., Falótico, M.B., Ferraz, E.S.B., Tomazelli, A.C., Salomão, M.S.M.B., Martinelli, L.A. and Victoria, R.L. Impact of anthropogenic activity on the $\mathrm{Hg}$ concentrations in the Piracicaba river basin (São Paulo State, Brazil). Water, Air, and Soil Pollution, 166(1-4), p. 381-402, 2005.

[6] Moreira, S., Fazza, E.V. Serra streams in the city of Limeira (Sp-Brazil) by Synchrotron Radiation Total Reflection X-ray Fluorescence. Spectrochimica Acta, 63(12), p. 1432-1442, 2008.

[7] Mortatti, J. and Probst, J.-L. Characteristics of heavy metals and their evaluation in suspended sediments from Piracicaba river basin (São Paulo, Brazil). Revista Brasileira de Geociências, 40(3), p. 375-379, 2010.

[8] Jardim, G.M., Armas, E.D. and Monteiro, R.T.R. Ecotoxicological assessment of water and sediment of the Corumbataí River, SP, Brazil. Brazilian Journal of Biology, 68(1), p. 51-59, 2008.

[9] Leite, M.A. Analysis of the input, sedimentation rate and metal concentration on the water, plankton and sediment of Salto Grande reservoir, Americana-SP. USP: São Carlos, Brazil, 2002 (in Portuguese).

[10] Bonotto, D.M. and Lima, J.L.N. de Pb-derived chronology in sediment cores evidencing the anthropogenic occupation history at Corumbataí River basin, Brazil. Environmental Geology, 50(4), p. 595-611, 2006.

[11] IBGE (Instituto Brasileiro de Geografia e Estatística). Cidades@ Available on http://www.ibge.gov.br/cidadesat/topwindow.htm?1 Access on February 2, 2013.

[12] SEPLAN (Secretaria de Planejamento - Unidade de Estatística e Análise Sócio Econômica da Prefeitura de Americana) Informativo sócioeconômico município de Americana - SP ano base 2011. SEPLAN: Americana, 2012. (in Portuguese). 
[13] CEPAGRI - Centro de Pesquisas Meteorológicas e Climáticas Aplicadas a Agricultura Clima dos municípios paulistas: Americana. Available on http://www.cpa.unicamp.br/outras-informacoes/clima_muni_019.html. Access on February 2, 2013.

[14] AWWA - American Public Health Association American Water Works Association/Water Environment Federation Standard Methods For The Examination Of Water And Wastewater. 20th ed. Washington: AWWA, 1999.

[15] CETESB - Companhia Ambiental do Estado do São Paulo Surface water quality in the State of São Paulo 2011. CETESB: São Paulo, 2012 (in Portuguese).

[16] Ure, A. M. Methods of analysis for heavy metals in soils (Chapter 4) Heavy metals in soils, ed. B. J. Alloway, Blackie Academic \& Professional: London, pp. 58-102, 1995.

[17] Basilio, M.S., Friese, K. and Lena, J.C. Adsorption of As, $\mathrm{Cu}, \mathrm{Pb}$ and $\mathrm{Cr}$ for the assessment of metal retention by two different residues from iron ore mines. Química Nova, 28(5), p. 822-828, 2005 (in Portuguese).

[18] CCME - Canadian Environmental Quality Guidelines. Sediment quality guidelines for the protection of aquatic life. Available on http://www.ccme.ca/publications/ceqg_rcqe.html Access on February 11, 2013.

[19] McGrath, S. P. Chromium and Nickel (Chapter 7) Heavy metals in soils, ed. B. J. Alloway, Blackie Academic \& Professional: London, pp.152-178, 1995.

[20] Baker, D. E. and Senft, J. P. Copper (Chapter 8) Heavy metals in soils, ed. B. J. Alloway, Blackie Academic \& Professional: London, pp.179-205, 1995.

[21] Davies, B. E. Lead (Chapter 9) Heavy metals in soils, ed. B. J. Alloway, Blackie Academic \& Professional: London, pp. 206-223, 1995.

[22] Kiekens, L. Zinc (Chapter 13) Heavy metals in soils, ed. B. J. Alloway, Blackie Academic \& Professional: London, pp. 284-305, 1995. 